\title{
Software Considerations for Sustainable Poverty Reduction
}

\author{
D.A. Adenugba \\ Department of Physics \\ The Federal University of Technology, Akure \\ P. M.B 704, Akure, Ondo State. Nigeria.
}

\begin{abstract}
This paper shows that poverty cannot be eradicated, but reduced to the level of living comfort. The causes, effects and solutions to poverty are addressed. The principle of tilling the ground to meet the geometrical wave of food insufficiency across the globe was discussed. The expected holy wedlock between farming and programming received due attention. Applications of Microsoft Visual Studio, 2010 to eleven models that are imperative inputs to Penman-Monteith and Priestly-Taylor equations depict that to achieve quick and drastic poverty reduction software applications should be further developed and integrated with equipment. We developed a dynamic VB.NET class library for soil heat flux, net radiation, psychometric constant, saturation vapour pressure, and slope of saturation vapour pressure curve, barometric pressure at various altitudes, actual vapour pressure, virtual absolute air temperature, mean atmospheric density and latent heat of vapourization. Besides, a flexible and accurate client application where our class functionalities were exposed was developed. Results from our package were compared with previous works and found to be in agreement. With our package, the use of look-up table is eliminated as the required value(s) could be estimated and presented in diverse formats dynamically for use and keep.
\end{abstract}

\section{General Terms}

Poverty, Vapourization, density

\section{Keywords}

Soil heat flux, eradication, reduction, PTillingSoft

\section{INTRODUCTION}

Broadly speaking, there are two groups of people in every society: the rich and the poor. Within these groups are subgroups. A person who cannot afford a thing he needs at a particular time is poor (Leviticus 14:21). Poverty has time frame and level. A person who is poor today may be rich tomorrow (Psalm 113:7). Also, a rich person may be transiently poor, including banks, state and even a nation. When a bank, for instance, sources for money from other banks to meet customers' urgent needs that bank is poor. Since no one can afford everything he needs at all times, then at one time or the other every person is poor. Most of our references will be taken from the Holy Bible (New King James Version, NKJV) because the message, though over five thousand years ago and with the old Jewish nation background, is very relevant to our situation today. Though not a religious paper, this paper will sip from the divine knowledge which God revealed to His people and prophets at various times in ancient time. No one who forgets his past makes much progress in the presence, and avoids errors and mistakes of the old.

If a needy person is always a poor person, then our definition here is perfectly right. However, a needy person is not necessarily and always a poor person. But a poor person is always a needy person. A needy is one who requires something to meet a need, either money or materials. In view of this, everybody is a needy, but not necessarily a poor person. In the illustration given above therefore the bank is a needy, not poor, requiring certain amount to meet an urgent need. Since a poor person is among everybody, he is thus a needy, but a needy incapable of meeting his need(s). A needy rendered by his income or environment or slothfulness or choice(s) or misplacement of priorities or combination of these, among others, from meeting his needs is a poor person. Thus, a poor person is not just a needy, but a terrible needy whose economic growth and income fail flatly to meet basic essential needs of living a minimal comfortable life (Proverbs 14:31). A person who has eaten plain rice, but is looking for fried rice graced with meat and eggs, is a comfortable needy, not a terrible needy. On-the-spot-needy, which could also be called Social-function-created-needy, is one who requires an item instead of the other given to him at that point; and owing to its availability, receives what he desires. This type of a needy is common at a social function where multiple items are served and demands freely granted by the celebrant(s) or server(s).

Social-function-created-needy is not a true needy just like a comfortable needy. There are needy people whose neighbours can bill them out of their plights as at when due, hence they are not really poor, but needy. But a terrible needy, who has no one to assist him out of his doldrums, is poor. This is a severe needy who could not afford three rectangular (unnourished) meals a day, let alone three square (nourished) meals. The Holy writ talks of poor and needy in a distinct way as to separate the duo (Psalm 37: 4). In the society, a poor person is regarded as one who could not meet most of his basic needs. Thus, he has permanent terrible state of penury, groping for basic needs which are not just forth coming.

Poverty may be a state of mind. This is when one feels he is poor (Proverbs 13:7). One who thinks he is poor is poor, yet he may be in millions. He will fail to use what he has for himself and others, since he believes he is poor. Indeed, poverty is relative and should be grasped in relation to typical living standards in society [1].

God created the poor and the rich (1 Samuel 2:7-8; Proverbs 22:2). The latter is to provide for the former out of his abundance which heaven gives to him. Even in the Jewish nation of old, the rich is to make provision for the poor and strangers out of their harvest (Leviticus 19:9-10; Deuteronomy 15:7-10). In order words, a poor person should be assisted in order to live. "You shall not lend him (the poor) your money for usury, nor lend him your food at a profit" (Leviticus 25:35-37; Exodus 22:25). To neglect to care for the poor is sinful. It provokes the wrath of the Lord. It is an abomination in the sight of God to mistreat, oppress and neglect the poor (Ezekiel 18:12-13; 22:29; Amos 4:1-2; 5:11$12 ; 8: 4)$. Sodom was condemned for his failure to care for the poor and needy (Ezekiel 16:49-50); Israel was marked for 
punishment for selling the poor for a pair of sandals (Amos 2:6).Today, if the governments of the nations learn from past history, poverty will not be as high as witnessed currently. It is sad to read that every three and a half seconds one person (children in particular) dies of hunger or hunger-related cause, amounting to 25,000 people dying daily [1-3].

That physical poverty appears in not less than twenty-six books of the Holy Bible and in more than sixty places in the Holy Bible, besides the people in authority daily talking about its elimination round the globe, depicts the need to take a deep look at it. We shall discuss the causes and effects of poverty on humanity, as well as solution to poverty reduction and the principle of program-tilling. We shall treat eleven models that are very essential to evaluating Penman-Monteith and Priestly-Taylor equations to demonstrate the usefulness and unmatched power of software packages in poverty reduction. Specifically, we shall develop a class library for soil heat flux, net radiation, psychometric constant, saturation vapour pressure, slope of saturation vapour pressure, barometric pressure at various altitudes, actual vapour pressure, mean atmospheric density, latent heat of vapourization and virtual absolute air temperature. A client application to expose the functionalities of our dynamic class will be produced.

\section{POVERTY}

Poverty has been from time immemorial; it is as old as the world. All over the world, especially in the developing nations, the focus now is on poverty eradication. Could poverty be eradicated? If it could, what will eradicate it? When will it be eradicated, 2015 or 2020 or beyond?

Contrary to peoples' notion, poverty cannot be eradicated through drinks. What drinks do is to make the uninformed temporarily forgets his misery. It cripples normalcy and promotes uncommon stupidity. Teasingly, the mother of King Lemuel has this to say: "Let him drink and forget his poverty, and remember his misery no more" (Proverbs 31:7). Anyone who reads from verses 1 to 6 of Proverbs 31 will not, but consent that this good mother is saying the wise King should abhor drinks as poison. In order to "Plead the cause of the poor and needy" (Proverbs 31:9), the King should abstain from drinks.

By creation poor people are bound to exist in every society and community. God didn't promise wealth and riches to everybody on earth, but daily bread. To wake up very early and sleep very last is not a guarantee of riches (Proverbs 10:22). Technological advancement does not eliminate poverty; else there won't be poor people in advanced nations. That there are poor folks in developed nations is an eloquent testimony to the fact that poor people will not cease to exist as long as this earth planet subsists. To talk glowingly of poverty eradication is a 21 st century exaggeration, and misguided zealousness that could lead to misplacement of priority and misdirected and procrastinated project design and execution.

Reduction is not the same thing as eradication. What the advanced nations have done is to reduce poverty to the barest minimum, which developing nations should endeavour to attain. What technology does is to create comfort, ease, speed and precision to a reasonable degree. Anyone who thinks technology has removal poverty or can do that is a day dreamer. No technology at present is designed to eradicate poverty. Rather what is closely observed is that it throws unskilful people in their millions out of job. It is undeniable fact that technology created highly skilful jobs for few skilful people. He who claims that poverty can be eradicated is poor of facts and figures, both from history and present day reality. There is spiritual and physical poverty. One who is destitute of sound faith is spiritually poor, which is not our focus in this paper.

God did not promise at any time that there won't be poor people. He knows the conditions for poverty eradication could not be met by any mortal. If mortal beings could meet God's conditions for poverty eradication (Deuteronomy 15:5) then poverty in our land will evaporate into thin air. Could all mortal keep God's commandments, the condition for poverty eradication, without defaulting in one? No! Thus, God's declaration settles the whole matter: "For the poor will never cease from the land" (Deuteronomy 15:11a); and Jesus said, "For you have the poor with you always.." (Matthew 26:11). With this divine declaration, poverty cannot be eradicated, no matter the level of technology on ground and that which may emanate later. However, it may be reduced as the opulent in the society open wide their hands to their poor human fellows (Deuteronomy 15:7-11).

Consequently, countries like Britain and America should cancel the debts of nations like Nigeria, Zimbabwe and Mali. Similarly, Nigeria should wipe off the debts of nations owing her. What this translates to is that poverty has levels. The hierarchy of poverty implies that each person, community, state and nation should be his brother's keeper. "You shall open your hand wide to your brother, to your poor and your needy, in your land" (Deuteronomy 15:11). America, we should not forget, had forgiven some debts of Nigeria, as well as other developing nations, but she needs to do more. This poor-rich, owing-forgiving relationship will never come to an end, as long as the world exists. It was in existence during the Patriarchal and Mosaic eras, and during this Christian age, the last age (Hebrews 1:1-3), it is with us.

\section{CAUSES OF POVERTY}

"Laziness casts one into a deep sleep, and an idle person will suffer hunger" (Proverbs 19:15). Idleness causes lack; lack leads to poverty (Proverbs $6: 10-11 ; 20: 13$ ). He who has a slack hand becomes poor; but the hand of the diligent makes rich (Proverbs 10:4). Also, "He who is slothful in his work is a brother to him who is a great destroyer"(Proverbs 18:9).

Stinginess could lead to poverty (Proverbs 11:24-26). Poverty could result owing to misplacement of priorities and incorrect choice(s) which may be due to failure to accept counsel (Proverbs 13:13, 18; 11:14; 19:20-21; 20:18; 24:6). Misplacement of priority is the cause of about 1.2 Billion people suffering from hunger [3]. To alleviate poverty is to go back to the base---farming. God, who cannot lie (Titus 1:2), has said it all: "He who tills his land will have plenty of bread" (Proverbs 28:19a). Report has it that the number of poor people in Africa has almost doubled between 1981 and 2001 [3], yet the size of land during this period remains the same. What this implies is that the number of young people farming has declined tremendously. Also, every succeeding Government in power pays sweet lip service to farming than addressing it pragmatically with mechanized farming.

All over Africa what is seeing is Television farming, where crops thrive and bumper harvest promises to eliminate hunger. When TV-farming gives way to land-cultivating crops, hunger will fizzle out, health will improve and life expectancy will increase. In addition, women worldwide will receive more care and their poverty line will drop drastically from the present $70 \%$. It is not alarming seeing the ICAP high figure of $70 \%$ poverty for females worldwide. For one, women are not weak vessels but weaker vessels (1 Peter 3:7), who should not be over-laboured. By nature, men are to provide for the weaker vessels, care and love them. In the face of hunger, this is far from being achieved. A hungry person is not only an 
angry fellow, but a loveless and selfish person.

Careless living in drunkenness and excessive pleasures is a potential causer of poverty (Proverbs 21:17; 23:21). Those who follow frivolity get sufficient poverty (Proverbs 28:19). The day the developing nations embrace mechanized farming with true commitments, the day plenty will smile on them; and they will be able to reduce their poverty enough to be called developed nations. The Yoruba adage says, when hunger is removed, poverty becomes a trivial issue. And hunger cannot be removed when the divine injunction in the Holy Bible is ignored. It is no gainsaying that industries and commerce largely depend on agricultural products. We insist that when men are back to the base, women and children will smile; the society will witness comfort in the midst of abundance. Why should Africa suffer hunger when her population increases daily, and her farming land is intact? Why should Africa be a "home to virtually all the Planets Ultra poor" [3]?

Unfavourable environment and unexpected inimical changes in climate and weather could cause sudden poverty. Natural disaster, without letter of warning and without atom of mercy, could render hitherto wealthy people poor and even crippled them. Famine is a common occurrence that could make rivers of tears flow down the cheeks of the rich. To be hasty to be rich could lead to poverty as the over-ambitious person will fall into "many foolish and hurtful lusts", and when caught will be disgraced and properties wrongfully amassed will be confiscated (Proverbs 28:22; 1Timothy 6:9).

Unused and misused talents could lead to poverty. Each person has a God-given talent(s) to enable him survive in this world. Unused talent is useless. Talent, no matter how little, when used helps people to make living. Combination of good talents could move mountains and pave way for better living conditions. Misused talent is a waste to humanity. Talent should be appropriately employed to better self and others. Besides, ill-gotten riches will come to nothing and inappropriate given to people leads to poverty (Proverbs 22:16).

Poor government policies, corruption, debt and poor management of the economy have been identified as major causes of poverty [3-4].

\section{TILLING THE GROUND}

Civilization has urbanized people; cleverly takes away farming and food from them and handover hunger to them. Fuelled by every succeeding Government lip-service and deep insincerity and corruption, people are further made to belief that hunger could be conquered through very few white collar jobs and/or by chasing over-prized Government contracts. Oil driven economy, with foundation on sinking sand, is a quest for easy way to reach the peak without solid foundation which tilling the ground provides.

Poverty reduction is not always the possession of more money. More money does not necessarily translate to more comfort and poverty reduction. Neither does abundance natural resources and vast land tantamount to poverty reduction and comfortable living. If it is, in most of the developing nations where there are copious natural resources, there will be drastic poverty reduction and hardship will reside in history rather than in the community ravaging both young and old. Money, it has correctly been noted, does not equate to happiness or peace of mind [6]. Although money answers all things (Ecclesiastes 10:19), yet "People who aim for money, power and fame above all else will find themselves wanting in the end" [6]. Nations require food sufficiency through program-tilling to gain and sustain health; earn respect and honour in the comity of nations. That is why focus in on achieving food security and reducing hunger [5]. In a land that never shrinks, in a land that is self-recuperating after fallow, in a land which is never tired in the presence of fertilizer, we live in perpetual hunger. Whose fault? The Lord has from the beginning of time shown to mankind the way to live in plenty and procure bliss on this earth planet. When the principle of tilling the ground was abandoned man started witnessing unprecedented suffering brought about by hunger. $\mathrm{O}$ that the nations go back to their God-ordained task, abundance will greet them; joy will flow like river in the wilderness. There is plenty of food in the world for everyone [7] through program-tilling. A nation who forsakes the principle of program-tilling will ever possess clean teeth and groaning stomach. He who has food has hope, strength and respect. The opposite is equally true.

True path to individual, state and national greatness is never in the absence of agriculture, which God, the creator of the universe, handed over to mankind from the beginning of time. True help to alleviate poverty should emphasis tilling the ground using modern equipment and technologies. Abundance is closely linked to farming, but swift plenty is a scrupulous holy matrimony between farming and programming. This imperative relationship between agriculture and programming, fittingly tagged program-tilling, is the panacea to putting an everlasting nail on the coffin of food insufficiency and hunger worldwide. According to a reliable source over $50 \%$ of Africa's population today lives below the poverty line; and sadly enough, over nine million people in the world die of hunger annually [1-3]. An enduring technology, as well as swift repetitive information generation is a sure product of programming. What a pot is to a sweet stew is what programming is to software applications. Also, what light is to darkness is what sufficiency is to hunger. When farming equipment principles are carefully merged with programming, farming equipment will be automated and insufficiency will meet with big positive challenge. The eating mode of $1-0-1$ or $0-0-1$ or 1-0-0, occasioned by insufficient food, will give way to 1-1-1 expected pattern of eating that will provide sound body resistance against diseases, and make life meaningful and comfortable.

A nation who neglects God's injunction of tilling the ground will never attain greatness. "Much food is in the fallow ground of the poor" (Proverbs 13:23a). Any organization in place or to be in place without solid programme for programtilling the ground won't achieve and record much success in its poverty alleviation programme(s). Any sincere person knows we need urgent solution to world food insufficiency. When food inadequacy is addressed through program-tilling, the world will witness unprecedented abundance of food, improved health, long-life and tremendous industrial growth which is resting on inerratic raw materials' supply from the soil.

\section{PROGRAM-TILLING PRINCIPLE}

Poverty is a lack of tilling the ground. Poverty does not depend on gender, colour or race or nation or religion. It cuts across developing and developed nations; religious and ethnic groups. For instance, in 2009/2010 in U.K before and after housing costs, the number of children living in poverty is respectively 2.6 and 3.8 million [1-3]. Poverty may be natural or self-made due to lack of program-tilling. Program-tilling is not unachievable through well-developed skill in computer programming, agric engineering, and Physics electronics; soil Physics and other related fields of study such as hydrology and Meteorology. The holy wedlock between the fields will 
unlock the hard soil for receiving different seeds that will grow to meet food insecurity. Unyielding soil in the subSaharan Africa where poverty is very high and infections and diseases reign supreme, claiming lives in millions due to lack of food, will smile in the face of automated farming equipment driven by one or more of the over one hundred well-developed computer programming languages in use at present.

Program-tilling is the unified principles of agriculture and software applications to automate farm tools and machines. We are not unaware that this is on in some institutions and citadel of learning all over the globe, especially in developed nations. But in most developing countries the skill and knowledge are begging for acquisition. What this means is that poor nations should focus efforts and human development on tilling the ground and software application development; while advanced nations should gear more efforts, energies and resources in these two areas.

\section{EFFECTS OF POVERTY}

Some of the terrible effects of poverty are lack of basic needs such as food, clothes, electricity, accommodation etc., and the inherent suffering and hardship, aside shame and reproach, associated with lack. Improper feeding reduces body immunity to fight diseases thus the body is susceptible to various debilities and sicknesses. Poverty could lead to destruction. "The destruction of the poor is their poverty" (Proverbs 10:15b).

Other damaging effects of poverty are: dysfunctional family and societal relationships, paralyzingly low self-esteem, and spiritual darkness [1].

\section{SOLUTIONS TO POVERTY}

Poverty could be at individual, family, community, state and nation levels. Although poverty may operate at the level of the individual, it has a widespread effect on the populace in the nation [8]. Therefore, poverty, like Cholera, is infectious and attempt to leave it unaddressed is ruinous. Poverty is not irreducible. Poverty of knowledge could be tackled by sending all the children to school to achieve reasonable reduction of illiteracy. Poverty of food is achievable by embarking on program-tilling. Spiritual poverty is attainable through proper reading, studying and interpretation of God's words (Colossians 3:16; 2 Timothy 2:15; Psalm 66:18; Psalm 119:11). True love and fellowship will lift up the poor from slum to a better living condition as the rich generously extend hands of fellowship to him. The kindness of the rich could remove $\mathrm{p}$ from poor and replace it with $\mathrm{d}$ for door of opportunity to be opened for him to be generator of goods and services which will improve his economic growth and that of the nation towards achieving nationhood and personal living comfort.

Truth and integrity could reduce poverty. There is something that is better than poverty: truth. A truthful poor man may be despised, yet he is far better than a liar. "And a poor man is better than a liar" (Proverbs 19:22b). Another thing far better than ill-gotten riches is integrity (Proverbs 19:1). When public funds are judiciously utilized, poverty will be reduced with the provision of basic amenities and infrastructures. This is in line with what [3] correctly observed that good governance, transparency and accountability are key components to alleviating poverty. Poverty could be alleviated through indigenous knowledge. It was found that disregard for indigenous knowledge caused deterioration of the environment. However, its application promoted traditional food production and preservation [5]. Moreover, timely information on self-improvement has been noted as sure way to alleviating poverty both in the rural and urban areas [8]. Software packages are good dynamic creator of interest, motivation and creativity. They are capable of reducing indolent. Laziness will be drastically reduced if there is interest in a task. Willingness is a driving intangible object that propels an individual or society to embark on a project, which good computer packages could provoke. Above all, to drastically and swiftly reduce poverty, people should further embrace software applications development and use those on ground.

\section{APPLICATIONS TO SOME MODELS}

The energy required in heating the soil, soil heat flux, G (MJm-2h-1) is expressed as [9-10, 12]

$$
G=0.1 R_{n}
$$

It is positive when the soil is warm and negative when it is cool. The net radiation $\mathrm{Rn}$ is related to solar radiation, $\mathrm{Rs}$ and net long-wave radiation, $\mathrm{Rnl}$ by

$$
R_{n}=0.77 R_{s}-R_{n l}
$$

The net radiation is greater than zero at daytime and less or equal to zero at night time. The latent heat of vaporization $\lambda$ (MJkg-1), saturation vapour pressure, es $(\mathrm{kPa})$ and slope of saturation vapour pressure curve, $\Delta(\mathrm{kPaC}-1)$ is given in relation to mean hourly air temperature, $\mathrm{Ta}(0 \mathrm{C})$ by

$\lambda=2.501-0.002361 T_{a}$

$e_{s}=0.6108 \exp \left[\frac{17.27 T_{a}}{T_{a}+237.3}\right]$

$\Delta=\frac{4099 e_{s}}{\left[T_{a}+237.3\right]^{2}}$

The slope in term of Ta only is given by $[10,12,15]$

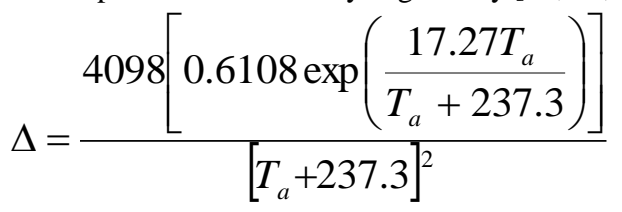

es in turn is related to the actual vapour pressure, ea $(\mathrm{kPa})$ by $e_{a}=e_{s} * \frac{R H}{100}$

The relative humidity, RH should not be greater than $100 \%$. The atmospheric pressure $\mathrm{P}(\mathrm{kPa})$ for varying altitudes, $\mathrm{z}(\mathrm{m})$ is expressed as $[11,14]$

$$
P=P_{0}\left[\frac{T_{a}-\eta \cdot Z}{T_{a}}\right]^{\frac{g}{\eta \cdot R}}
$$

Where $\mathrm{P} 0(\mathrm{kPa})$ is the atmospheric pressure at sea level with numeric value of $101.3 \mathrm{kPa}$. The reference air temperature, Ta (0C) is 293.16. The lapse rate, $\eta_{\text {is }} 0.0065 \mathrm{Km}-1$. The gravitational acceleration at sea level $\mathrm{g}$ and the specific gas constant, $\mathrm{R}$ are respectively given as $9.807 \mathrm{~m} / \mathrm{s} 2$ and $287 \mathrm{Jkg}$ $1 \mathrm{~K}-1$. The mean atmospheric density, $\rho_{(\mathrm{kgm}-3)}$ is expressed as $[11,13]$ 


$$
\rho=\frac{1000 \times P}{R \times T_{V}}
$$

Where the virtual absolute air temperature, $\mathrm{Tv}$ is related to air temperature, Ta by [11]

$$
T_{V}=c .\left[T_{a}+273.16\right]
$$

Ta may be daily or hourly air temperature; $\mathrm{c}$ is a constant parameter given by 1.01 ; and when it is 1 and $\mathrm{P}=100$, an approximate mean atmospheric density for green house environments is obtained which is useful in Stanghellini equation.

The Psychometric constant is given by [9]

$$
\gamma=0.00163 \frac{P}{\lambda}
$$

All these equations are mandatory inputs for PenmanMonteith equation, apart from their use in other situations. For instance, the actual vapour pressure is extensively employed in propagation models and Priestly-Taylor equation uses mean atmospheric density.

\section{CLASS LIBRARY}

A dynamic class library, ProgramTillingCls was developed using Microsoft VB.NET. The method for computing soil heat flux, G has three arguments: The TimeType is an enumerate class which has two members for specifying daytime and night time. The second argument is also an enumerating class for indicating which evapotranspiration (ETo) is required to be calculated. The last argument is Rn value to use. The second overload of the method accepts Rs and Rnl, instead of $\mathrm{Rn}$, as inputs. With the careful design here, there is no need to write separate soil heat flux for each ETo. All that is required is to specify which ETo to compute and the method will switch to fetch the appropriate constant (c), as well as bulk surface resistance and aerodynamic resistance coefficient, $\mathrm{Cd}$, to use. Since $\mathrm{Cd}$ is not required for $\mathrm{G}$ estimation, a separate function (dvGetConsts) is written for $\mathrm{c}$ and $\mathrm{Cd}$ values retrieval, so that it could be called with ease. dvGetConsts function is called in the method and the $\mathrm{c}$ is used to compute accurate result which is returned through a class-level declared object variable. Other methods and functions were written for all the models above.

\section{CLIENT APPLICATION}

Figure 1 is the user interface of our application where the class library functionalities are exposed. The package functions and features are seen directly on this figure. When Continue main menu is clicked another user interface (which space prevent us from showing) is displayed which has seven main menus and different submenus.

\section{RESULTS AND DISCUSSION}

Tables 1-11 present the results for all the models considered. The day and night time soil heat fluxes are shown in Table 4. Tables 1, 5-11 could be presented in varying rows (length) according to user's requirement. By setting row equal to 6 , we obtained Table 8 which conserves space vertically than Tables 5-7. Table 5 does not include pressure $(\mathrm{P})$ calculated by using the input altitude (altd), yet $\mathrm{P}$ has to be computed before psychometric constant (Psy) is calculated (see eqn 11). The instruction to do this and include $\mathrm{P}$ in Table 6 was passed through an enumerate class to one of the methods for psy computation. Although Tables 5-6 use constant latent heat of vaporization (LHVP) to test our package and compare results with previous work [10], diverse values were utilized in Tables 7-8. Table 9 is the correct result for eqn (6), while Table 10 computes for eqn (5). The results are identical showing that either equation could suffice for slope result, depending on available input(s). Table 11 could be outputted in another form (no space to show more results); and $\mathrm{RH}<0$ and $\mathrm{RH}>100 \%$ are effectively trapped and reported to user of our package.

Meteorological Tables could be generated and presented dynamically to satisfy user's taste which conventional method could not achieve. The required essential constant(s) to use for evaluation could be estimated and made available for use as at when needed promptly. Besides, a full table of constants to use with specified length (row) could be produced. Space won't permit the display of many results, but let's know that one hundred thousand data could be accepted and processed in a tinkling of an eye which superhuman being cannot achieve, thus confirming the unparalleled strength of software in poverty reduction as myriad of tasks could be tackled timely, accurately and efficiently. Not only could varying length of table of constants be produced, our method eliminated the use of static constant tables which is prone to error in looking up for constant(s) to use for estimation, aside wasting precious time and energy.

By having various ways of formatting and inputting data into the methods and outputting results, we give cheap but highly essential flexibility and effects to the user of our servers. By using lesser time to accomplish tasks, more time is possessed for other precious things. Thus, poverty could be reduced programmatically as more time is made available, and difficult and repetitive tasks solved promptly. All the results obtained agree with previous works [9-11]. 


\section{WELCOME TO PTILLINGSOFT

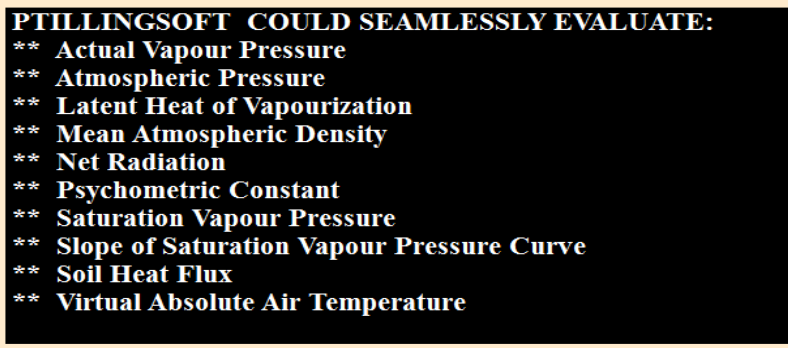 \\ FEATURES OF PTILLINGSOFT \\ ACCURATE \\ FAST \\ FLEXIBLE \\ RELIABLE \\ BENEFICIARIES Include: \\ * Researchers \\ * Scientists \\ ${ }^{*}$ Educators \\ * Learners}

Figure 1: Main User Interface for PTillingSoft Package

Table 1: Atomspheric Pressure

$\begin{array}{cccc}\text { Altd, } \mathbf{z} & \mathbf{P} & \text { Altd,z } & \mathbf{P} \\ 0 & 101.3 & 400 & 96.7 \\ 100 & 100.1 & 450 & 96.1 \\ 150 & 99.5 & 600 & 94.4 \\ 200 & 99 & 750 & 92.8\end{array}$

Table 3: Mean Atomspheric Density

Temp,Ta P Tv=1.01*(Ta+273.16) Rho

\begin{tabular}{cccr}
20 & 101.3 & 29 \\
16 & 898 & 29 \\
4.7 & 567 & 28 \\
22 & \multicolumn{2}{c}{534} & 29 \\
\multicolumn{4}{c}{ Table 5: Psychometric } \\
Altd & LHVP & Psy \\
0 & 2.45 & 0.067 \\
100 & 2.45 & 0.067 \\
200 & 2.45 & 0.066 \\
300 & 2.45 & 0.065 \\
400 & 2.45 & 0.064
\end{tabular}

Table 7: Psychometric Constant

$\begin{array}{cccccc}\text { Alt } & \text { P } & \text { LHVP } & \text { Psy } & \text { Alt } & \text { P } \\ 0 & 101.3 & 2.45 & 0.067 & 0 & 101.3 \\ 100 & 100.125 & 3.7 & 0.044 & 100 & 100.125 \\ 200 & 98.961 & 2.45 & 0.066 & 200 & 98.961 \\ 300 & 97.808 & 4.5 & 0.035 & 300 & 97.808 \\ 400 & 96.665 & 2.45 & 0.064 & 400 & 96.665 \\ 500 & 95.534 & 1.5 & 0.104 & 500 & 95.534 \\ 600 & 94.413 & 2.45 & 0.063 & & \end{array}$

Table 9: Slope of Vapour Pressure, $S$
$\begin{array}{llllll}\mathbf{T} & \mathbf{S} & \mathbf{T} & \mathbf{S} & \mathbf{T} & \mathbf{S}\end{array}$
$\begin{array}{llllll}1 & 0.047 & 6 & 0.065 & 11 & 0.087\end{array}$
$\begin{array}{llllll}\text { es } & \text { Ta } & S & \text { es } & \text { Ta } & S\end{array}$
$\begin{array}{llllll}0.657 & 1 & 0.047 & 0.785 & 3.5 & 0.055\end{array}$

Table 2: Virtual absolute temperature, Tv

$\begin{array}{cc}\text { Temp, Ta } & \text { Tv } \\ 4 & 277.16 \\ 8 & 281.16 \\ 10 & 283.16 \\ 12 & 285.16\end{array}$

Table 4: Net Radiation

Rn Flux (Daytime) Flux(Nighttime)

$\begin{array}{ccc}2 & 2.00 \mathrm{E}-01 & 1.00 \mathrm{E}+00 \\ 6 & 6.00 \mathrm{E}-01 & 3.00 \mathrm{E}+00 \\ 10 & 1.00 \mathrm{E}+00 & 5.00 \mathrm{E}+00 \\ 2 & 2.00 \mathrm{E}-01 & 1.00 \mathrm{E}+00\end{array}$

Table 6: Psychometric Constant

$\begin{array}{cccc}\text { Altd } & \text { P } & \text { LHVP } & \text { Psy } \\ 0 & 101.300 & 2.45 & 0.067 \\ 100 & 100.125 & 2.45 & 0.067 \\ 200 & 98.961 & 2.45 & 0.066 \\ 300 & 97.808 & 2.45 & 0.065 \\ 400 & 96.665 & 2.45 & 0.064\end{array}$

Table 8: Psychometric Constant

LHVP Psych Altd P LHVP Psy

$\begin{array}{llllll}2.45 & 0.067 & 600 & 94.413 & 2.45 & 0.063\end{array}$

$\begin{array}{llllll}3.7 & 0.044 & 700 & 93.303 & 0.45 & 0.338\end{array}$

$\begin{array}{llllll}2.45 & 0.066 & 800 & 92.204 & 2.45 & 0.061\end{array}$

$\begin{array}{llllll}4.5 & 0.035 & 900 & 91.115 & 2.5 & 0.059\end{array}$

$\begin{array}{llllll}2.45 & 0.064 & 1000 & 90.036 & 7.35 & 0.02\end{array}$

$1.5 \quad 0.104$

Table 10: Slope of Vapour Pressure, $S$ 


$\begin{array}{cccccccccccc}1.5 & 0.049 & 6.5 & 0.067 & 11.5 & 0.09 & 0.681 & 1.5 & 0.049 & 0.813 & 4 & 0.057 \\ 2 & 0.05 & 7 & 0.069 & 12 & 0.092 & 0.706 & 2 & 0.051 & 0.842 & 4.5 & 0.059 \\ 2.5 & 0.052 & 7.5 & 0.071 & 12.5 & 0.095 & 0.731 & 2.5 & 0.052 & 0.872 & 5 & 0.061\end{array}$

Table 11: Saturation vapour pressure

$\begin{array}{cccccccccc}\text { Ta } & \text { es } & \text { Ta } & \text { es } & \text { Ta } & \text { es } & \text { Ta } & \text { es } & \text { Ta } & \text { es } \\ 1 & 0.657 & 3.5 & 0.785 & 6 & 0.935 & 8.5 & 1.11 & 11 & 1.313 \\ 1.5 & 0.681 & 4 & 0.813 & 6.5 & 0.968 & 9 & 1.148 & 11.5 & 1.357 \\ 2 & 0.706 & 4.5 & 0.842 & 7 & 1.002 & 9.5 & 1.187 & 12 & 1.403 \\ 2.5 & 0.731 & 5 & 0.872 & 7.5 & 1.037 & 10 & 1.228 & 12.5 & 1.449 \\ 3 & 0.758 & 5.5 & 0.903 & 8 & 1.073 & 10.5 & 1.27 & & \end{array}$

\section{CONCLUSION}

If a politician talks of poverty eradication, it is a political deceit to lure people to vote for him/her. If an academician speaks and/or writes that poverty could be eradicated that is a hypothesis or academic fraud to the path of political office. Poverty cannot be eradicated. God decreed it, and nothing can alter it. We should start talking about poverty reduction and put up plans and designs to actualize this noble goal. More poverty alleviation programmes in other areas apart from agriculture and software development emphasis in this paper should be set up and those on ground should be adequately funded. However, henceforth, those clamouring for poverty eradication should think thrice, not twice, as they betray lack of proper understanding of what poverty is and what God says concerning it.

Let us focus pragmatically on high comfort-given programmes which are achievable if realistically pursued and faithfully implemented, instead of phoney unachievable poverty eradication. The robust, flexible and accurate class library developed was utilized to produce an accurate client package, PTillingSoft. Researchers and developers will find our server and package beneficial in their works. More models should be included in this work.

\section{REFERENCES}

[1] endpoverty :www.endpoverty.org

[2] United Nations Development Programme:www.undp.org/governance/focus_womensempowerment.shtml

[3] International Center for Alleviation of Poverty, Inc. (ICAP) www.povertyalleviation.org/projects.htm

[4] wikipedia :www.en.wikipedia.org/wiki/proverty/
[5] unescap :www.unescap.org/62/English/E1380e.pdf

[6] Salvador B. Cariaga (Year, not given).

Happiness. The Voice of Truth International. Vol. 16.

[7] poverty :www.poverty.org.uk

[8] Isoun, T.T. 2002. Speech of the Honourable Minster of Science and Technology at the First Regional Workshop on Satellite. Commun- ications. 16-20 September, 2002 at OAU, Ile-Ife. Nigeria.

[9] www.cimis.water.ca.gov.Rich with facts and figures

[10] www.fao.org. FAO Corporate Document Repository. Crop Evapotranspiration---- Guidelines for Computing Crop Water Requirements.

[11] agsys :http://agsys.cra-cin.it

[12] Tetens, O., 1930. Uber einige meteorologische Begriffe. z. Geophys. 6:297-309.

[13] Murray, F.W. 1967. On The Computation of Saturation Vapor Pressure. J. Appl. Meteor. 6: 203-204.

[14] Burman, R.D, M.E. Jensen, and R.G. Allen, 1987. Thermodynamic factors in Evapo- transpiration. In: James L.G., English M.J. (eds.) Proc. Irrig. And Drain. Spec. Conf., ASCE, Portland, Oregon, USA, July 1987, 28-30.

[15] Smith, M., R.G. Allen, J.L. Monteith, A. Pervier, L. Pereira, and A. Segeren. 1991. Report of the expert consultant on procedures for revision of FAO guidelines for prediction of crop water requirements. Food and Agri- culture Organization of the United Nations, Rome, Italy 